DOI https://doi.org/10.36059/978-966-397-154-4/216-231

\title{
PHYTOSANITARY CONDITIONS OF WINTER CEREAL CROPS ON THE IRRIGATED LANDS OF THE SOUTH OF UKRAINE DEPENDING ON THE AGROMETEOROLOGICAL CONDITIONS OF THE YEAR
}

\section{Zaiets S. O.}

\section{INTRODUCTION}

One of the most significant reasons, which destabilize the production of grain and worsen its quality both on irrigated and non-irrigated lands of the South of Ukraine is a significant infestation of plants by fungal diseases, the losses of yield from them reach $20-30 \%$, and in the years of epiphytoties they are even higher ${ }^{1,2,3,4}$.

In recent years, phytopathological situation with crops in the South of Ukraine has slightly changed. In most cases, this is due to the climate change. Firstly, there are quite extreme-arid weather conditions observed before and after the sowing period of winter cereal crops. Secondly, the late cessation of the autumn vegetation of plants (this period is prolonged by 12 - 15 days) and early regrowth (in the third decade of February - early March), accompanied by sharp fluctuations in the night (minus) and daytime (plus) air temperatures. Under such conditions, additional tillering occurs on the winter crops, plants weaken, and extreme (dry) conditions in the spring period of vegetation lead to a change in the phytopathologic condition of the crops.

If in the South of Ukraine in the 80-90s of the last century winter cereal crops were mainly infested by smut diseases, brown rust and powdery mildew, then in the last decade - the agents of the leaf spotting: winter

\footnotetext{
1 Коваленков В.Г. Усложняющаяся фитосанитарная ситуация требует новых решений. Защита и карантин растений. 2010. 7. С.4-7.

${ }_{2}^{2}$ Ретьман С. В. Плямистості пшениці в Лісостепу України й концептуальні основи захисту: автореф. дис. на здобуття наук. ст. доктора с.-г. наук: спец. 06.01.11 «Фітопатологія». К., 2009. 43 с.

3 Судникова В. П. Создание исходного материала для селекции пшеницы на устойчивость к Septoria tritici Rob. et Desm. Пути решения проблем повышения адаптивности, продуктивности и качества зерновых и кормовых культур: Материалы междунар. практич. конф. Самара, 2003. С. 103.

${ }_{4}^{4}$ Samobor V. Effect of powdery mildew attack on guality parameters and experimental bread baking of wheat. Acta agriculturae Slovenica. 2006. B. 87, № 2. P. 381-391.
} 
wheat by Septoria spot (Septoria tritici Desm.), and winter barley by net blotch (Drechslera teres lto) ${ }^{5}$.

Therefore, researches on the monitoring of the main phytopathogens of winter cereal crops on the irrigated lands of the South of Ukraine, as well as identification of the most plastic varieties to them, are very relevant.

\section{Agrometeorological conditions of the spring-summer period of winter crops vegetation in 2016, 2017 and 2018}

Field experiments were conducted in 2016 - 2018 on the irrigated lands of the Institute of Irrigated Agriculture of NAAS. The soils are darkchestnut, slightly alkaline, middle-loamy, with humus content of $2.3 \%$. The bulk density of a meter layer of the soil is $1.37 \mathrm{~g} / \mathrm{cm}^{3}$. The field capacity (FC) is $20.3 \%$ of the weight of the completely dry soil, and the wilting point (WP) is $9.1 \%$. Meteorological parameters that determined the weather conditions of the spring-summer period of winter cereal crops in 2016, 2017 and 2018 were taken from the observations of the Regional Center of Hydrometeorology in Kherson ${ }^{6,7}$. Distinctive feature of the vegetative period of cereal crops in 2016 was sufficiently high amount of precipitation: in March - $19.5 \mathrm{~mm}$, April - $56.8 \mathrm{~mm}$; May - $71.7 \mathrm{~mm}$ and June - $43.0 \mathrm{~mm}$ (Table 1). During the vegetative period (from April to June) was $171.5 \mathrm{~mm}$ of precipitation, which is by $52.9 \mathrm{~mm}$ more than the norm. A slightly different situation was observed in 2017 and 2018 years. Only in April of 2017 and March of 2018 there were more precipitation than the norm: 60.4 and $35.2 \mathrm{~mm}$, respectively. In the other months, there was a significant shortage of precipitation and high temperatures, especially in 2018. For April - June 2018, there was $60.4 \mathrm{~mm}$ of precipitation, which is $58.2 \mathrm{~mm}$ less than the norm.

The level of the provision with water of winter cereal crops during the vegetative period was determined by the humidity coefficient. Its indexes in moderately humid $(25 \%)$ by precipitation 2016 year was 0.70 , while the perennial norm is 0.40 . In 2017, the humidity coefficient during the vegetation period was 0.59 , which is more than by 0.19 over the norm. And in 2018 , the humidity coefficient was the least and averaged to 0.12 . Therefore, to maintain moisture in the soil layer of $0-50 \mathrm{~cm}$ at the level of $70 \% \mathrm{FC}$, it was enough to

\footnotetext{
${ }^{5}$ Бублик Л.І., Васечко Г.І., Васильєв В.П. та ін. Довідник із захисту рослин. За ред. М.П. Лісового. Київ: Урожай, 1999. 744 с.

${ }_{6}^{6}$ Агрометеорологічний бюлетень по території Херсонської області за першу, другу і третю декади вересня, жовтня і листопада 2015 p. № № 25-33. URL: http://khersonpogoda.ks.ua.

7 Агрометеорологічний бюлетень по території Херсонської області за 2016, 2017 і 2018 pp. № №1-33. Режим доступ URL: http://khersonpogoda.ks.ua.
} 
carry out only water-charging irrigation with the norm of $500 \mathrm{~m}^{3} /$ ha in 2016 , and there was a need in two and three vegetation watering irrigation with the norm of 800 and $1350 \mathrm{~m}^{3} /$ ha in 2017 and 2018 , respectively.

Table 1

Meteorological conditions of the vegetative period of 2016, 2017 and 2018 in comparison to the average perennial indexes for 1945-2010

\begin{tabular}{|c|c|c|c|c|c|c|}
\hline \multirow[b]{2}{*}{ Month } & \multicolumn{6}{|c|}{ Indexes } \\
\hline & $\begin{array}{c}\text { Average air } \\
\text { temperature, } \\
{ }^{\circ} \mathrm{C}\end{array}$ & $\begin{array}{l}\text { Relative air } \\
\text { humidity,\% }\end{array}$ & $\begin{array}{c}\text { Amount of } \\
\text { precipitation, } \\
\text { mm }\end{array}$ & $\begin{array}{c}\text { Evaporation, } \\
\text { Mm }\end{array}$ & $\begin{array}{c}\text { Water } \\
\text { deficiency, } \\
\text { Mm }\end{array}$ & $\begin{array}{l}\text { Humidity } \\
\text { coefficient }\end{array}$ \\
\hline \multicolumn{7}{|c|}{ Moderately humid by precipitation 2016 year } \\
\hline March & 6.3 & 78 & 19.5 & 38.7 & 19.2 & 0.50 \\
\hline April & 12.6 & 71 & 56.8 & 73.8 & 17.0 & 0.77 \\
\hline May & 16.1 & 76 & 71.7 & 73.3 & 1.6 & 0.98 \\
\hline June & 22.1 & 68 & 43.0 & 127.8 & 84.8 & 0.34 \\
\hline $\begin{array}{c}\text { For IV - } \\
\text { VI }\end{array}$ & 16.9 & 71.7 & 171.5 & 274.9 & 103.4 & 0.70 \\
\hline \multicolumn{7}{|c|}{ Moderate by precipitation 2017 year } \\
\hline March & 7.0 & 73 & 5.1 & 49.8 & 44.7 & 0.10 \\
\hline April & 9.3 & 72 & 87.9 & 59.3 & -28.6 & 1.48 \\
\hline May & 16.3 & 64 & 25.6 & 110.5 & 84.9 & 0.23 \\
\hline June & 22.0 & 61 & 10.3 & 147.1 & 136.8 & 0.07 \\
\hline $\begin{array}{c}\text { For IV - } \\
\text { VI }\end{array}$ & 15.9 & 65.7 & 123.8 & 316.9 & 193.1 & 0.59 \\
\hline \multicolumn{7}{|c|}{ Moderately dry by precipitation 2018 year } \\
\hline March & 1.5 & 75 & 61.2 & 31.6 & -29.6 & 1.94 \\
\hline April & 14.1 & 58 & 1.6 & 115.6 & 114.0 & 0.01 \\
\hline May & 19.5 & 59 & 35.7 & 146.1 & 110.4 & 0.24 \\
\hline June & 22.9 & 51 & 23.1 & 202.4 & 179.3 & 0.11 \\
\hline $\begin{array}{c}\text { For IV - } \\
\text { VI } \\
\end{array}$ & 18.8 & 56.0 & 60.4 & 464.1 & 403.7 & 0.12 \\
\hline $\begin{array}{c}\text { Perennial } \\
\text { norm } \\
(1945- \\
2010) \\
\end{array}$ & 15.5 & 66.7 & 118.6 & 299.7 & 181.1 & 0.40 \\
\hline
\end{tabular}

\section{Phytosanitary conditions of new winter wheat varieties} on the irrigated lands depending on the meteorological conditions

Winter wheat is one of the main food crops in the structure of the croplands of private and collective farms of Southern Steppe of Ukraine. Its yield and grain quality depends on many factors, among which one of the most important is the phytosanitary condition of crops $^{8}$. Our researches are dedicated to the

8 Заєць С.О., Коваленко О.А., Василенко Р.М. та ін. Ресурсозберігаючі екологічно безпечні технології вирощування озимих зернових культур, сої i кукурудзи на зрошуваних землях півдня України. Наукові основи адаптації систем землеробства до змін клімату в Південному Степу України: монографія; за наук. ред. чл.-кор. НААН Р. А. Вожегової. Херсон: ОЛДІ-ПЛЮС, 2018. С. 500-574. 
investigation of the phytosanitary condition of new and modern varieties of winter wheat when it is cultivated after soybean in the conditions of irrigation and to the detection of the most tolerant (resistant) to common fungal diseases among them. The varieties of winter wheat Ovidii, Ledia, Maria, Konka, Burgunka and Anatoliya, which are included in the State Register of plant varieties, suitable for distribution in Ukraine since 2009, 2016, 2013, 2014, 2015 and 2015, respectively, were sown. All the varieties of winter wheat were created at the Institute of Irrigated Agriculture of NAAS. The varieties of Ovidii and Ledia have a spine-free type of ear, and other varieties are spiny ones. It was established that in the conditions of 2016, 2017 and 2018 at irrigation the greatest harm for the wheat was caused by fungal diseases of leaves and stems, among the most widespread and harmful diseases were causative agents of septoriosis (Septoria tritici Desm.), pyrenophorosis (Drechslera tritici-repentis Died.), powdery mildew (Blumeria graminis (DC) Speer.) and yellow rust (Puccinia striiformis) (photo 1).

However, the monitoring of phytosanitary condition showed that in all the years of the research, the plants of winter wheat were infested by septoriosis (S. Tritici Desm.), while other diseases appeared only in certain years.

In agrometeorological conditions of 2016, the plants of winter wheat varieties were infested by the pathogens of septoriosis ( $S$. Tritici Desm.) and pyrenophorosis (D. Tritici-repentis Died.). Depending on the variety, spreading of these diseases at the earing stage, respectively, was 51.5-72.5 and $61.0-65.5 \%$, and the development -24.0-44,0 and 26.0-34.0\% (Table. 2). The greatest manifestation of septoriosis on the leaves was on the variety Ovidii, where the spreading rate reached $72.5 \%$, and the development $44.0 \%$. Tolerance (resistance) to damage of the leaves by septoriosis was on the varieties of Konka and Anatoliya, in which the development of this disease was 24 and $26 \%$, respectively.

Maria and Burgunka were the most resistant varieties to the damage of the leaves by pyrenophorosis, on which the prevalence of disease, respectively, was 62.0 and $61.0 \%$, and the development -26.0 and $28.0 \%$. The most affected by this disease were plant varieties of spine-free type Ovidii and Ledia, on which the development of this disease was 32 and 34\%, and the prevalence -65.5 and $64.0 \%$.

In the conditions of irrigation in 2017, the plants of winter wheat were affected by the leave form of septoriosis ( $S$. Tritici) and powdery mildew (B. Graminis), but to a lesser extent than in 2016. Therefore, the spreading and development of these diseases in 2017 was not significant and, correspondingly, it was $19.1-39.7$ and $0.9-2.0 \%$. 
Table 2

Spreading and development of fungal diseases on the leaves of winter wheat plants depending on the variety and agrometeorological conditions of the year

\begin{tabular}{|c|c|c|c|c|c|c|c|c|c|c|c|c|}
\hline \multirow{4}{*}{ Variety } & \multicolumn{12}{|c|}{ During the earing-milk ripeness of grain } \\
\hline & \multicolumn{4}{|c|}{2016} & \multicolumn{4}{|c|}{2017} & \multicolumn{4}{|c|}{2018} \\
\hline & \multicolumn{2}{|c|}{ I* } & \multicolumn{2}{|c|}{ II* } & \multicolumn{2}{|c|}{$I^{*}$} & \multicolumn{2}{|c|}{ III* } & \multicolumn{2}{|c|}{ I* } & \multicolumn{2}{|c|}{ IV* } \\
\hline & $\mathbf{R} * *$ & $\mathbf{R} * *$ & $\mathbf{P} * *$ & $\mathbf{R} * *$ & $\mathbf{R} * *$ & $\mathbf{R} * *$ & $\mathbf{P} * *$ & $\mathbf{R} * *$ & $\mathbf{R}_{*}^{*}$ & $\mathbf{R} *$ & $\mathbf{P} * *$ & $\mathbf{R} * *$ \\
\hline Ovidii & 72.5 & 44.0 & 65.5 & 32.0 & 39.7 & 1.9 & 0 & 0 & 100 & 6.3 & 5.0 & 1.0 \\
\hline Ledia & 64.0 & 30.0 & 64.0 & 34.0 & 30.8 & 1.1 & 0 & 0 & 100 & 2.8 & 2.0 & 0.05 \\
\hline Mar & & & 2.0 & 20 & 39. & 2. & 3.0 & 1.8 & 100 & 5.9 & 2.0 & 0.04 \\
\hline Konka & 1.5 & 24. & 3.0 & 30.0 & 19. & 0.9 & 2.2 & 1.6 & 100 & 4.3 & 0 & 0 \\
\hline Burgunk: & 5.0 & 32.0 & 1.0 & 28.0 & 33. & 1.5 & 2.7 & 1.6 & 100 & 2.3 & 100 & 2.0 \\
\hline Anatoliya & 52.5 & 26.0 & 62.5 & 30.0 & 25.7 & 1.9 & 0.6 & 1.1 & 100 & 3.8 & \begin{tabular}{|l|}
100 \\
\end{tabular} & 3.2 \\
\hline $\begin{array}{c}\bar{X} \bar{X} \mathrm{~S}_{\mathrm{X}}^{-} \\
\mathrm{S}_{\mathrm{X}}^{-} S_{\bar{X}}^{-}\end{array}$ & $\begin{array}{c}60.7 \\
\pm 3.7\end{array}$ & $\begin{array}{r}32.3 \\
\pm 3.1\end{array}$ & $\begin{array}{c}63.0 \\
\pm 0 \\
6\end{array}$ & $\begin{array}{c}30.0 \\
\pm 1 \\
2\end{array}$ & $\begin{array}{c}31.9 \\
\pm 8.4\end{array}$ & $\begin{array}{c}1.6 \pm \\
0.5\end{array}$ & $\begin{array}{c}1.4 \pm \\
1.4\end{array}$ & $\begin{array}{c}30.0 \\
\pm 1 \\
2\end{array}$ & $\begin{array}{l}100 \\
\pm 0\end{array}$ & $\begin{array}{c}4.2 \pm \\
1.7\end{array}$ & $\begin{array}{l}34.8 \\
\pm 75\end{array}$ & $\begin{array}{c}1.0 \pm \\
2.0\end{array}$ \\
\hline $\mathrm{V}, \%$ & 14.8 & 23.3 & 2.51 & 9.43 & 25.7 & 29.9 & 2.51 & 96.5 & 0 & 38.1 & 145 & 125 \\
\hline
\end{tabular}

Note: * I-Septoria tritici Desm.), II-Pyrenophorosis (Drechslera tritici-repentis Died.), III-Powdery mildew (Blumeria graminis (DC) Speer.); IV - Yellow rust (Puccinia striiformis Wesst).

$* * P$-prevalence of disease, $\% ; R$-disease development, $\%$.

The most distribution of septoriosis disease has reached 39.7 and $39.6 \%$ on the varieties of Ovidii and Maria with the development of the disease of 1.9 and $2.0 \%$, respectively. On the varieties of Konka, Ledia and Burgunka, the development of this disease was the least and at the earing stage, respectively, it was $0.9,1.1$ and $1.5 \%$.

The causative agent of mildew (B. Graminis) affected the plants of the spiny varieties of winter wheat Maria, Konka, Anatoliya and Burgunka, where the spreading and the development of this disease, respectively, was $3.0 ; 2.2 ; 2.7$ and $0.6 \%$ and $1.8 ; 1.6 ; 1.6$ and $1.1 \%$. The spine-free plant varieties Ovidii and Ledia were not affected by powdery mildew.

In 2018, the plants of winter wheat were also affected by septoriosis (S. Tritici), the distribution of which in all the varieties reached $100 \%$ at the stage of grain ripeness. But the development of this disease was insignificant, and fluctuated from 2.3 to $6.3 \%$ in dependence on the variety. This year, the infestation of winter wheat plants by the causative agent of yellow rust (Puccinia striiformis) was fixed, which development on the varieties Burgunka and Anatoliya was 2.0 and $3.2 \%$. On the variety of Konka, the disease of yellow rust was not found, and on all the other varieties there was an insignificant its manifestation.

On average for three years of the research on the plants of winter wheat, the development and spreading of septoriosis disease (S. Tritici) depended on the biological properties of the variety and averaged to $56.9-70.7 \%$ and $9.7-17.4 \%$ (Fig. 1). 


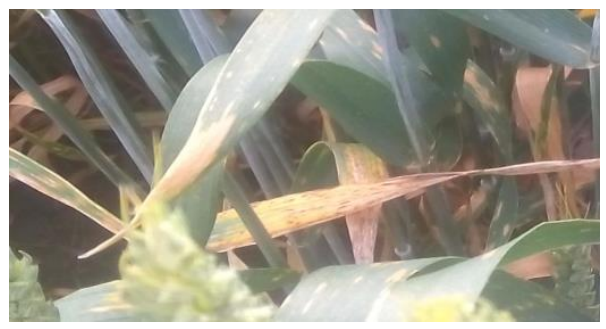

Septoriosis of leaves (Septoria tritici Desm.)

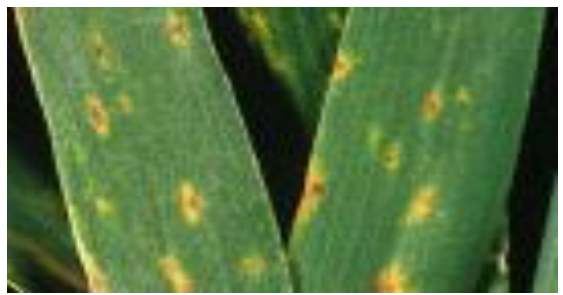

Pyrenophorosis of leaves (Drechslera tritici-repentis Died.)

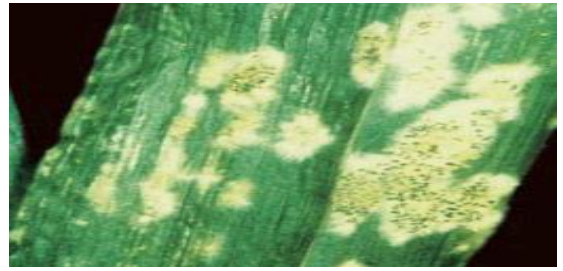

Powdery Mildew (Blumeria graminis (DC) Speer.)

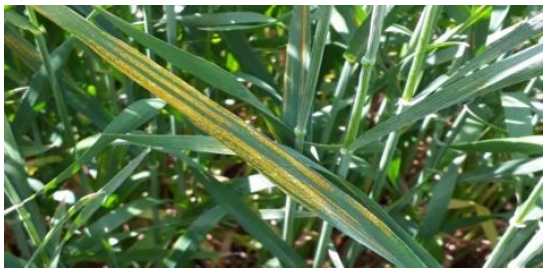

Yellow Rust (Puccinia striiformis Wesst)

Photo 1. Diseases of winter wheat at irrigation in the conditions of 2016-2018 


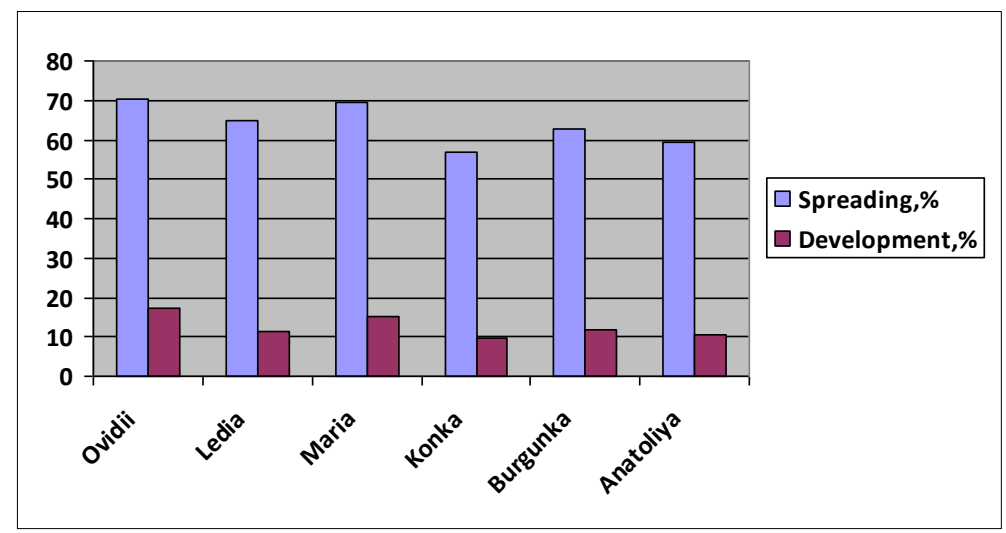

Fig. 1. The spreading and development of septoriosis ( $S$. Tritici Desm.) on the leaves of the winter wheat plants depending on the variety, (average for 2016-2018)

The least infestation with the disease was on the plant varieties Konka and Anatoliya, and the most - on Ovidii. The results of the grain yield evaluation showed that its level was influenced by the degree of propagation and development of the diseases. Taking into account that in 2016 winter wheat varieties Konka and Anatoliya were more resistant to septoriosis, and the variety Maria to pyrenophorosis, they provided the higher yields of 7.43, 7.38 and $7.50 \mathrm{t} / \mathrm{ha}$ (Table. 3 ).

Table 3

Yields of new and modern winter wheat varieties depending on the development of fungal diseases, $t / \mathrm{ha}$

\begin{tabular}{|c|c|c|c|c|c|}
\hline No. & Variety & $\mathbf{2 0 1 6}$ & $\mathbf{2 0 1 7}$ & $\mathbf{2 0 1 8}$ & $\begin{array}{c}\text { Average for 2016- } \\
\mathbf{2 0 1 8}\end{array}$ \\
\hline 1 & Ovidii & 6.88 & 6.41 & 7.41 & 6.90 \\
\hline 2 & Ledia & 7.24 & 6.74 & 6.92 & 6.97 \\
\hline 3 & Maria & 7.50 & 7.06 & 7.83 & 7.46 \\
\hline 4 & Konka & 7.43 & 7.16 & 7.56 & 7.38 \\
\hline 5 & Burgunka & 7.29 & 7.20 & 7.87 & 7.45 \\
\hline 6 & Anatoliya & 7.38 & 7.07 & 7.04 & 7.16 \\
\hline
\end{tabular}

$L S D_{05}$, t/ha $0.37 ; 0.26 ; 0.36 ; 0.14$.

While the less resistant to the diseases variety Ovidii formed by 0.50 $0.62 \mathrm{t} / \mathrm{ha}$ lower yield, which was $6.88 \mathrm{t} / \mathrm{ha}$, on the other investigated varieties Burgunka and Ledia, which were more resistant to spotting than Ovidii, 
grain yield, respectively, reached 7.29 and $7.24 \mathrm{t} / \mathrm{ha}$, which is 0.41 and $0.36 \mathrm{t} / \mathrm{ha}$ higher.

A similar situation on the formation of grain yield of the varieties of winter wheat was observed under the phytosanitary conditions of 2017. That is, varieties Konka and Burgunka, which are more resistant to fungal diseases, provided a higher yield of 7.16 and 7.20 t/ha, respectively. Less resistant to these diseases variety Ovidii formed 0.75 and 0.79 t/ha lower yield, which averaged to $6.41 \mathrm{t} / \mathrm{ha}$.

On the other investigated varieties Anatoliya and Maria, which were more resistant to the disease than Ovidii, 7.07 and $7.06 \mathrm{t} / \mathrm{ha}$ of grain yield was obtained, which is 0.66 and $0.65 \mathrm{t} / \mathrm{ha}$ higher. The variety of spine-free type Ledia, although more resistant to septoriosis and powdery mildew, but formed the yield of $6.74 \mathrm{t} / \mathrm{ha}$, which is $0.32-0.42 \mathrm{t} / \mathrm{ha}$ less than of the spiny varieties. This can be explained by the fact that this variety is ripening later, and it is falling under the «fire» of high air temperatures.

Taking into account that in 2018 the plants of Burgunka variety were not considerably affected by septoriosis and yellow rust, it provided the highest yield of $7.87 \mathrm{t} / \mathrm{ha}$. The lowest yield of grain of $6.92 / \mathrm{ha}$ was formed by the variety Ledia, due to its later ripening and getting under the «fire» of high air temperatures, because the percentage of disease infestation was not high.

On the other studied varieties Maria, Konka, Ovidii and Anatoliya, due to the more infestation by the causative agent of septoriosis, in comparison to the variety Burgunka, we obtained by $0.04,0.31,0.46$ and $0.83 \mathrm{t} / \mathrm{ha}$ lower yield of grain, respectively, which was 7.83, 7.56, 7.41, and 7.04 t/ha. However, the significant grain losses were provided by the varieties Ovidii, Ledia and Anatoliya. Almost the same yield in this year was by the formed varieties Maria, Burgunka and Konka. These varieties on average of three years of the research provided the highest yield levels - 7.46, 7.45 and $7.38 \mathrm{t} / \mathrm{ha}$. The lowest yield of grain of $6.90 \mathrm{t} / \mathrm{ha}$ was collected on the variety Ovidii, which was the most susceptible to infestation with fungal diseases of leaves among all the varieties.

\section{The phytosanitary condition of new varieties of winter barley on the irrigated lands depending on the meteorological conditions}

Barley is one of the most valuable fodder cereal crops. Ukraine entered into the four largest producers of this crop. It should be noted that over the past 15 years, the sown area of barley in Ukraine decreased by 2.3 times: from 5.8 million hectares (2003) to 2.5 million hectares (2018). However, the proportion of winter barley among cereal crops increased, while the share of spring barley was considerably reduced. Significant areas of sowing 
are concentrated in the South of Ukraine in Odesa, Mykolaiv and Kherson regions, where almost every year over 400 thousand ha are sown. According to the state Statistics Service of Ukraine, in 2018 the sowing area of winter barley was 872.6 thousand hectares, and yields were $3.35 \mathrm{t} / \mathrm{ha}$. Although the yield of barley increased by $68 \%$, it is almost two times lower than the yield in the EU countries.

One of the reasons leading to the loss of grain yield is the infestation and damage of the plants by harmful organisms ${ }^{9}$. Variety breeding, which are resistant against the defeat of fungal diseases, is of a great importance in the protection of winter barley ${ }^{10,11}$. In recent years, breeders of scientific institutions of the National Academy of Agrarian Sciences of Ukraine have created a number of varieties of typical winter and alternate types, which are distinguished not only by the increased frost-, or heat resistance, but also are more resistant to common diseases.

Therefore, the purpose of the research was to determine the phytosanitary condition of modern and new varieties of winter barley during the cultivation after soybean in the conditions of irrigation and the establishment among them the most resistant to common fungal diseases. Monitoring of phytosanitary conditions was conducted on the varieties of winter barley Aivengo, Akademichnyi, Burevii, Deviatyi Val, Dostoinyi and Snigova Koroleva, which are included into the State Register of plant varieties, suitable for distribution in Ukraine, respectively, in 2011, 2011, 2013, 2014, 2006 and 2014.

All of the studied winter barley varieties were created at the Selective Genetic Institute - The National Center for Seed and Varietal Studies of NAANS. The varieties Akademichnyi and Burevii are typical winter, and Aivengo, Deviatyi Val, Snigova Koroleva, and Dostoinyi are of alternate type.

It should be noted that in all the years of the research plants of winter barley varieties were infested by net blotch (Drechslera teres lto), and in the certain years - rhynchosporosis (Rhynchosporium graminicola Heinsen), powdery mildew (Blumeria graminis Speer) and yellow rust (Puccinia striiformis West) (Photo 2).

${ }^{9}$ Біловус Г.Я. Плямистості ячменю та заходи 3 обмеження їх розвитку в умовах Лісостепу України: автореф. дис. на здобуття наук ступеня канд. с.-г. наук: спец. 06.01.11 «Фітопатологія». К., 2006. 19 с.

10 Ковальский И.Д., Унтила И.П., Рожкован В.В., Караджова Л.В. Доноры устойчивости ярового ячменя к болезням в условиях Молдавской ССР. Съезд генетиков и селекционеров Молдавии. Кишинев: Штиинца, 1981. С. 81-82.

${ }^{11}$ Кузнецова Т.Е. Селекция ячменя на устойчивость к болезням. Краснодар, 2006. 288 с. 
The most spreading and development among the spot disease of leaves was in 2016, under the agrometeorological conditions in which the plants of winter barley were infested by net blotch (Drechslera teres 1to) and stripe (Drechslera graminea lto) helmintosporosis. Dostoinyi was not resistant to net blotch among the varieties of barley, on which the development of the disease reached $50 \%$ (Table 4). Slightly fewer were infestations by stripe helmintosporosis (D. teres lto) on the varieties Akademichnyi and Aivengo, on which the development of the disease was 46 and 44\%, respectively. The best resistance to net blotch was marked on the variety Deviatyi Val, where the development of the disease was $20 \%$ with the spreading of $58 \%$.

Barley stripe (D.Graminea lto) infested the plants of varieties Burevii, Aivengo, Akademichnyi and Dostoinyi, on which the development of the disease was 34, 32, 30 and 30\%, and the spreading - 67, 64, 69 and 63.5\%, respectively. Higher resistance to stripe had the varieties Deviatyi Val and Snigova Koroleva, on which the disease development was 26 and 28\%, respectively.

In the agrometeorological conditions of 2017 under the conduction of vegetative watering of the plants of winter barley, the plants were infested by net blotch (D. teres 1to) and rhynchosporosis (Rhynchosporium graminicola Heinsen), the distribution and development of which was 50.6-76.6\% and 2.0-10.6\%, respectively. The variety Dostoinyi was less resistant to net blotch, on which the spreading of the disease $76.6 \%$, and the development of the disease was $10.6 \%$. The varieties Deviatyi Val and Aivengo were tolerant to the causative agent of this disease - at the distribution of 50.6 and $54.0 \%$ the development averaged to 8.2 and $2.0 \%$, respectively.

The variety Dostoinyi was also less resistant to rhynchosporosis ( $R$. graminicola Heinsen), on which the maximum prevalence and development of this disease was observed, that is, respectively, 81.4 and $16.1 \%$. In agrometeorological conditions of 2018 , there was a need of three vegetation watering, which contributed to the spreading of such pathogens of fungal diseases: net helmintosporosis (Drechslera teres lto), powdery mildew (Blumeria Graminis Speer) and yellow rust (Puccinia striiformis West).

Manifestation of the pathogens of net helmintosporosis (D. teres LTO) and powdery mildew (B. Graminis Speer) on the plants of all winter barley varieties in the conditions of 2018 reached $100 \%$. As in the previous years, the maximum development of this disease was on the plants of the variety Dostoinyi, on which it averaged to $45.8 \%$. The varieties Aivengo and Burevii were resistant to net helmintosporosis (D. teres lto), on which the least development of this disease was fixed -3.4 and $6.0 \%$. 


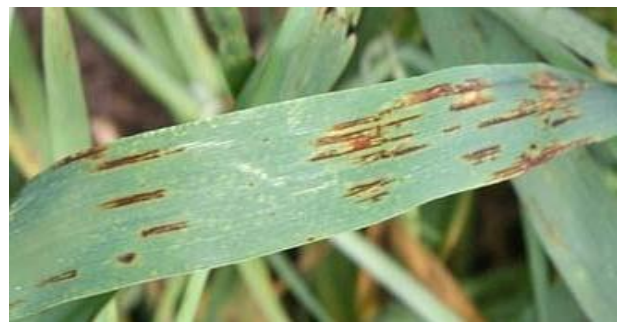

Net blotch (Drechslera teres Ito)

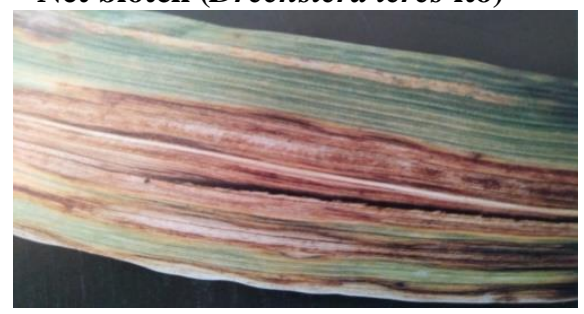

Barley stripe (Drechslera graminea lto),

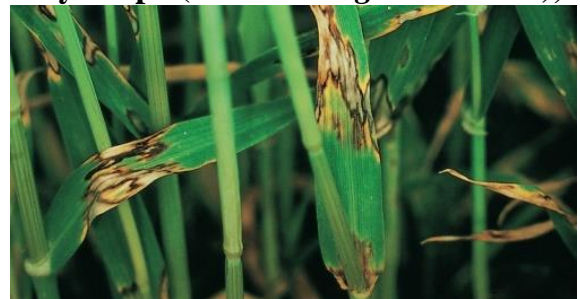

Rhynchosporosis blight (Rhynchosporium graminicola Heinsen)

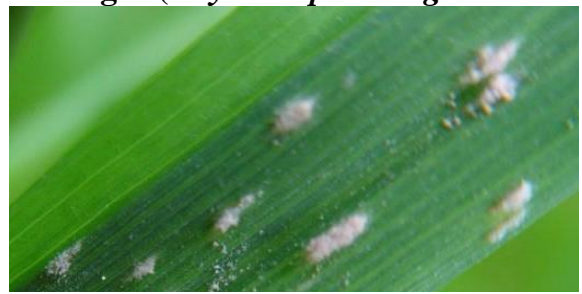

Powdery Mildew (Blumeria graminis Speer)

Photo 2. Diseases of winter barley at irrigation in the conditions of 2016-2018 
Table 4

The spreading and development of fungal diseases on the leaves of the winter barley varieties in 2016, 2017 and 2018

\begin{tabular}{|c|c|c|c|c|c|c|c|c|c|c|c|c|c|c|}
\hline \multirow{4}{*}{ Variety } & \multicolumn{14}{|c|}{ At the earing stage } \\
\hline & \multicolumn{4}{|c|}{2016} & \multicolumn{4}{|c|}{2017} & \multicolumn{6}{|c|}{2018} \\
\hline & \multicolumn{2}{|c|}{$\mathrm{I}$} & \multicolumn{2}{|c|}{ II } & \multicolumn{2}{|c|}{ I } & \multicolumn{2}{|c|}{ III } & \multicolumn{2}{|r|}{ I } & \multicolumn{2}{|c|}{ IV } & \multicolumn{2}{|c|}{$\mathrm{V}$} \\
\hline & $\mathrm{R} * *$ & $\mathrm{R} * *$ & $\mathrm{R} * *$ & $\mathrm{R} * *$ & $\mathrm{R} * *$ & $\mathrm{R} * *$ & $\mathrm{P} * *$ & $\mathrm{R} * *$ & $\begin{array}{c}\mathrm{P} * \\
*\end{array}$ & $\begin{array}{c}\mathrm{R} * \\
*\end{array}$ & $\begin{array}{c}\mathrm{P} * \\
*\end{array}$ & $\begin{array}{c}\mathrm{R} * \\
*\end{array}$ & $\mathrm{P} * *$ & $\begin{array}{c}\mathrm{R} * \\
*\end{array}$ \\
\hline Aivengo & 73.5 & 44 & 64.0 & 32 & 54.0 & 2.0 & 63 & 10.7 & 100 & 3.4 & 100 & 2.4 & 13.2 & 0.13 \\
\hline Akademichnyi & 76.5 & 46 & 69.0 & 30 & 59.7 & 8.6 & 63.6 & 4.8 & 100 & 14.4 & 100 & 1.8 & 5.1 & 0.19 \\
\hline Burevii & 63.0 & 28 & 67.0 & 34 & 56.6 & 3.5 & 67.6 & 6.6 & 100 & 6.0 & 100 & 2.8 & 10.3 & 0.14 \\
\hline Deviatyi Val & 58.0 & 20 & 59.5 & 26 & 50.6 & 8.5 & 68.3 & 15.2 & 100 & 7.4 & 100 & 2.9 & 100 & 5.0 \\
\hline Dostoinyi & 79.0 & 50 & 63.5 & 30 & 76.6 & 10.6 & 81.4 & 16.1 & 100 & 45.8 & 100 & 3.0 & 15.4 & 0.26 \\
\hline $\begin{array}{c}\text { Snigova } \\
\text { Koroleva }\end{array}$ & 73.0 & 42 & 67.5 & 28 & 60.0 & 5.6 & 65 & 10.1 & 100 & 4.2 & 100 & 2.5 & 100 & 6.9 \\
\hline $\begin{array}{c}\bar{X} \bar{X}_{ \pm} \mathrm{S}_{\mathrm{X}}^{-} \mathrm{S}_{\mathrm{X}}^{-} \\
S_{\bar{X}}^{-}\end{array}$ & $\begin{array}{c}70.5 \\
\pm \\
3.3\end{array}$ & $\begin{array}{c}38.3 \\
\pm \\
4.8 \\
\end{array}$ & $\begin{array}{c}65.0 \\
\pm \\
1.4 \\
\end{array}$ & $\begin{array}{c}30.0 \\
\pm 1 \\
2 \\
\end{array}$ & $\begin{array}{c}59.6 \\
\pm \\
8.8 \\
\end{array}$ & $\begin{array}{c}6.4 \\
\pm \\
3.2 \\
\end{array}$ & $\begin{array}{c}68.2 \\
\pm \\
6.6 \\
\end{array}$ & $\begin{array}{r}10.6 \\
\pm 4.4\end{array}$ & $\begin{array}{l}100 \\
\pm 0\end{array}$ & $\begin{array}{l}13.5 \\
\pm 15\end{array}$ & $\begin{array}{l}100 \\
\pm 0\end{array}$ & $\begin{array}{c}2.6 \pm \\
0.4\end{array}$ & $=\begin{array}{l}40,7 \\
\pm 48\end{array}$ & $\begin{array}{l}2.1 \pm \\
3.2\end{array}$ \\
\hline $\mathrm{V}, \%$ & 11.6 & 30.5 & 5.3 & 9.4 & 15.2 & 51.4 & 10.0 & 42.5 & 0 & 120 & 0 & 17.2 & 113 & 144 \\
\hline
\end{tabular}

Note: *I-net blotch (Drechslera teres lto), II - barley stripe (Drechslera graminea lto), III - rhynchosporosis (Rhynchosporium graminicola Heinsen); IV-powdery mildew (Blumeria graminis Speer); $V$-yellow rust (Puccinia striiformis West) $* * P$ - prevalence of disease, \%; $R$-disease spreading, $\%$.

The development of powdery mildew (B. Graminis Speer) on the plants of winter barley varieties was insignificant. But the maximum of its development the disease also gained on the variety Dostoinyi $-3.0 \%$. Less infested by mildew among all the varieties was Akademichnyi, on which the development averaged to $1.8 \%$.

Also, in 2018 on the winter barley crops we observed slight manifestation of the disease caused by the causative agent of yellow rust (Puccinia striiformis Wesst).

On average for the years of the research, on the plants of winter barley the development of the pathogen of net helmintosporosis (D. teres 1to) depended on the characteristics of the variety and was $69.5-85.2 \%$ and $12.0-35.5 \%$, respectively (Fig. 2).

The varieties Deviatyi Val and Burevii were more resistant to this disease, the spreading of the disease on which, respectively, averaged to 69.5 and $73.2 \%$, and the development -12.0 and $12.5 \%$. The plants of the variety Dostoinyi were non-resistant to the pathogen of net helmintosporosis (D. teres lto).

It was established that the level of grain yield depended on the spreading and development of the fungal diseases.

Taking into account that in the agrometeorological conditions of 2016 the variety of winter barley Deviatyi Val was more resistant to net blotch, 
and Snigova Koroleva - to barley stripe, they provided the highest yield of 6.97 and $7.27 \mathrm{t} / \mathrm{ha}$, respectively (Table. 5).

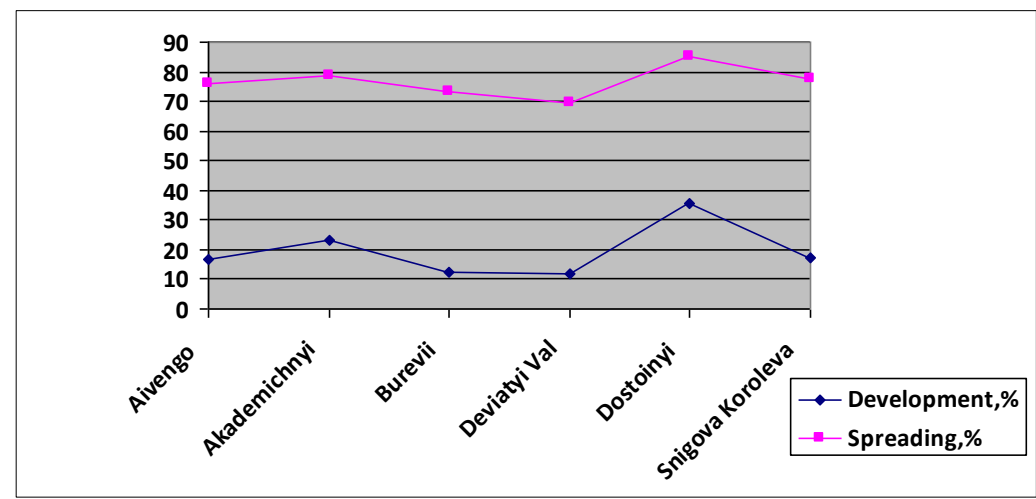

Fig. 2. The spreading and development of net blotch (Drechslera teres lto) on the leaves of the plants of winter barley depending on the variety, (average for 2016-2018)

Table 5

Yield of new and modern varieties of winter barley depending on the development of fungal diseases, $\mathrm{t} / \mathrm{ha}$

\begin{tabular}{|c|c|c|c|c|c|}
\hline No. & Variety & 2016 & 2017 & 2018 & $\begin{array}{c}\text { Average for 2016- } \\
2018\end{array}$ \\
\hline 1 & Aivengo & 6.39 & 6.80 & 7.82 & 7.00 \\
\hline 2 & Akademichnyi & 6.67 & 6.46 & 7.53 & 6.89 \\
\hline 3 & Burevii & 6.02 & 6.41 & 7.36 & 6.60 \\
\hline 4 & Deviatyi Val & 6.97 & 6.58 & 7.17 & 6.91 \\
\hline 5 & Dostoinyi & 5.69 & 6.18 & 6.62 & 6.16 \\
\hline 6 & $\begin{array}{c}\text { Snigova } \\
\text { Koroleva }\end{array}$ & 7.27 & 6.31 & 7.17 & 6.92 \\
\hline
\end{tabular}

$L S D_{05}$, t/ha $0.97 ; 0.24 ; 0.43 ; 0.34$.

While less resistant to these diseases variety Dostoinyi formed significantly lower yield, which was $5.69 \mathrm{t} / \mathrm{ha}$, that is 1.58 and $1.28 \mathrm{t} / \mathrm{ha}$ less than of the varieties snigova Koroleva and Deviatyi Val.

On the varieties Akademichnyi, Aivengo and Burevii we harvested, respectively, 6.67, 6.39 and $6.02 \mathrm{t} / \mathrm{ha}$ of grain, which is by $0.98,0.70$ and $0.33 \mathrm{t} / \mathrm{ha}$ higher than on the variety Dostoinyi. But the additional yield of 
0.70 and $0.33 \mathrm{t} / \mathrm{ha}$, received on the varieties of Aivengo and Burevii, was mathematically not significant $\left(\mathrm{LSD}_{05}\right.$ is $0.97 \mathrm{t} / \mathrm{ha}$ ).

The similar influence of the pathogens of fungal diseases on the formation of winter barley yield was observed in 2017. That is, the varieties Aivengo, Deviatyi Val and Akademichnyi, which are more resistant to net helmintosporasis and rhynchosporosis, provided higher yields of $6.80,6.58$ and $5.46 \mathrm{t} / \mathrm{ha}$, respectively. While less resistant to these diseases variety Dostoinyi formed significantly lower yield, which was $6.18 \mathrm{t} / \mathrm{ha}$, that is by $0.62,0.40$ and $0.28 \mathrm{t} / \mathrm{ha}$ less than of the varieties Aivengo, Deviatyi Val and Akademichnyi ( $\mathrm{LSD}_{05}$ is equal to $0.24 \mathrm{t} / \mathrm{ha}$ ).

The analysis of the results of the grain yield in 2018 showed that on the varieties of winter barley Aivengo, Akademichnyi and Burevii, the development of the disease of net helmintosporosis, powdery mildew and yellow rust was much lower than their harmful threshold. Therefore, compared to other varieties, they provided higher yield, which was 7.82, 7.53 and $7.36 \mathrm{t} / \mathrm{ha}$, respectively.

While less resistant to these diseases variety Dostoinyi formed significantly lower yield, which was $6.62 \mathrm{t} / \mathrm{ha}$, that is by $1.2,0.91,0.74,0.55$ and $0.55 \mathrm{t} / \mathrm{ha}$ less than of the varieties Aivengo, Akademichnyi, Burevii, Deviatyi Val and Snigova Koroleva, respectively ( $\operatorname{LSD}_{05}$ is $0.43 \mathrm{t} / \mathrm{ha}$ ).

On average for three years of the research, the highest levels of yield 7.00, 6.92, 6.91 and $6.89 \mathrm{t} / \mathrm{ha}$ were provided by the varieties Aivengo, Snigova Koroleva, Deviatyi Val and Akademichnyi. The lowest yield of grain of $6.16 \mathrm{t} / \mathrm{ha}$ was harvested on the variety Dostoinyi, which was mostly infested by the pathogens of fungal leave diseases among all the studied varieties.

\section{CONCLUSIONS}

1. It was determined that in the conditions of irrigation the greatest infestation of winter wheat is caused by such fungal diseases of leaves and stems as: septoriosis (Septoria tritici Desm.), pyrenophorosis (Drechslera tritici-repentis Died.), powdery mildew (Blumeria graminis (DC) Speer.) and yellow rust (Puccinia striiformis). However, in all the years of the research, the plants of winter wheat were infested by septoriosis ( $S$. Tritici Desm.), while other diseases were only in certain years.

2. It was determined that on the natural background of infection all the studied in the conditions of irrigation varieties of winter wheat were infested with fungal diseases in different degrees. The varieties Konka and Anatoliya were the most resistant to the causative agent of septoriosis (S. Tritici Desm.), Maria and Burgunka - to pyrenophorosis (D. Tritici-repentis Died), 
Ovidii, Ledia and Anatoliya - to powdery mildew (B. Graminis), Konka, Maria and Ledia - to yellow rust ( $P$. Striiformis).

3. It was established that in all the years of the research the plants of winter barley varieties were infested with net blotch (Drechslera teres 1to), while the other fungal diseases (Rhynchosporium graminicola Heinsen), powdery mildew (Blumeria graminis Speer) and yellow rust (Puccinia striiformis West) manifested only in certain years.

4. In the conditions of irrigation the varieties Deviatyi Val and Burevii are the most resistant to net blotch (Drechslera teres 1to); Deviatyi Val - to barley stripe (Drechslera graminea lto); Akademichnyi and Burevii - to rhynchosporosis (Rhynchosporium graminicola Heinsen); Akademichnyi to powdery mildew (Blumeria graminis Speer); Aivengo and Burevii - to yellow rust (Puccinia striiformis West). The variety of alternate type Dostoinyo was not resistant to the above-mentioned pathogens.

\section{SUMMARY}

Taking into account that one of the essential reasons that destabilize the production of grain and deteriorates its quality is a significant infestation of plants by fungal diseases, the determination of the phytosanitary condition of new varieties of winter cereal crops in the conditions of irrigation is especially relevant. It is established that on the plants of winter wheat the largest distribution and development had septoriosis disease (S. Tritici) and it was dependent on the biological characteristics of the variety - 56.9 $70.7 \%$ and $9.7-17.4 \%$, respectively. The least disease infested were the plants of the varieties Konka and Anatoliya, and the most infested one was Ovidii. In the plants of winter barley the manifestation and development of the most widespread pathogens of fungal diseases such as net helmintosporosis ( $D$. teres lto) was also dependent significantly on the characteristics of the variety $-69.5-85.2 \%$ and $12.0-35.5 \%$, respectively. More resistant to this disease were the varieties Deviatyi Val and Burevii, and non-resistant one was Dostoinyi.

\section{REFERENCES}

1. Коваленков В.Г. Усложняющаяся фитосанитарная ситуация требует новых решений. Защита и карантин растений. 2010. 7. С.4-7.

2. Ретьман С. В. Плямистості пшениці в Лісостепу України й концептуальні основи захисту: автореф. дис. на здобуття наук. ст. доктора с.-г. наук: спец. 06.01.11 - «Фітопатологія». К., 2009. 43 с.

3. Судникова В. П. Создание исходного материала для селекции пшеницы на устойчивость к Septoria tritici Rob. et Desm. Пути решения 
проблем повышения адаптивности, продуктивности и качества зерновых и кормовых культур: Материалы междунар. практич. конф. Самара, 2003. С. 103.

4. Samobor V. Effect of powdery mildew attack on guality parameters and experimental bread baking of wheat. Acta agriculturae Slovenica. 2006. B. 87, № 2. P. 381-391.

5. Бублик Л.І., Васечко Г.І., Васильєв В.П. та ін. Довідник із захисту рослин. За ред. М.П. Лісового. Київ: Урожай, 1999. 744 с.

6. Агрометеорологічний бюлетень по території Херсонської області за першу, другу і третю декади вересня, жовтня і листопада 2015 p. № №25-33. URL: http://khersonpogoda.ks.ua.

7. Агрометеорологічний бюлетень по території Херсонської області за 2016, 2017 i 2018 pp. № № 1-33. Режим доступ URL: http://khersonpogoda.ks.ua.

8. Заєць С.О., Коваленко О.А., Василенко Р.М. та ін. Ресурсозберігаючі екологічно безпечні технології вирощування озимих зернових культур, сої і кукурудзи на зрошуваних землях півдня України. Наукові основи адаптації систем землеробства до змін клімату в Південному Степу України: монографія; за наук. ред. чл.-кор. НААН Р. А. Вожегової. Херсон: ОЛДІ-ПЛЮС, 2018. С. 500-574.

9. Біловус Г.Я. Плямистості ячменю та заходи 3 обмеження їх розвитку в умовах Лісостепу України: автореф. дис. на здобуття наук ступеня канд. с.-г. наук: спец. 06.01.11 «Фітопатологія». К., 2006. 19 с.

10. Ковальский И.Д., Унтила И.П., Рожкован В.В., Караджова Л.В. Доноры устойчивости ярового ячменя к болезням в условиях Молдавской ССР. Съезд генетиков и селекционеров Молдавии. Кишинев: Штиинца, 1981. С. 81-82.

11. Кузнецова Т.Е. Селекция ячменя на устойчивость к болезням. Краснодар, 2006. 288 с.

\section{Information about the author: \\ Zaiets S. O.,}

Candidate (Ph.D.) of Agricultural Sciences, Senior Researcher, Head of the Department of Agrotechnologies,

Institute of Irrigated Agriculture of the National Academy of Agrarian Sciences of Ukraine Kherson, Naddnipryanske, 73483, Ukraine 